English from 1999 up to January 2017 were considered for inclusion based on a systematic search of Pubmed.

Results In total 50 intervention studies have been included in this review including, but not limited to, studies in the metal industry (10), hospitals (4), bakeries (3), on welding (6) or dust in construction (4). Overall the interventions reviewed have succeeded at reducing exposure levels. However, a direct comparison of a specific RMM among different studies, even when focussing on one specific sector of industry, remains difficult due to the heterogeneity in assessment methods; in addition, the quantification of the impact of individual interventions on exposure remains difficult as the majority of studies assessed the implementation of a set of different RMMs.

Conclusion There is evidence that decreases in workplace exposure levels to hazardous substances followed a variety of workplace interventions in a variety of industries underlining the benefits of implementing RMMs at workplaces.

\section{THE POLITICS OF DUST SUPPRESSION IN SPANISH COAL MINING, 1944-1975}

Alfredo Menéndez-Navarro. History of Science Department, University of Granada, Granada, Spain

\subsection{6/oemed-2018-ICOHabstracts.542}

Introduction Historiography has revealed a complex combination of scientific, technical, socio-political, economic, and cultural factors affecting the identification of occupational risks and the adoption of corrective measures and compensation schemes. In the case of coal dust, the late recognition of pneumoconiosis as an occupational disease of coal workers in the 1940s was largely because the hazard of silica overshadowed that of coal dust. In the case of Spain, the coal mining industry had a period of expansion in the 1940s and 1950s, when its traditional lack of competitiveness with British coal was overcome by autarchic protectionism under Franco regime. This gave rise to an intensification of workloads and the worsening of working conditions, converting coal workers' pneumoconiosis into the main industrial disease in Franco's Spain. The preventive approach to coal dust problem has received scant attention from historians. Thus, the aim of this paper is to explore the politics of preventive approaches against coal dust diseases during the Franco regime.

Methods A historiographical analysis of the rich documentation kept in the archives of Spanish coal mining companies has been carried out.

Results Apart from medical monitoring, very little action was taken on dust suppression until the early 1960s. Despite the costs of compensation in this period, employers failed to take voluntary action to address the dust problem. Changing strategies developed after nationalisation of the sector in 1967

Discussion The growing labour unrest and political concerns about rising pneumoconiosis rates in the late 1950s led to the updating of the Code of Mining Safety Regulations (1960), which for the first time included regular dust control measurements. After nationalisation, the new public corporation (HUNOSA) focused more on prevention than compensation, developing a more technical approach to dust suppression.
754

CARLO VALLARDI (1886-1962). AN ASSISTANT OF LUIGI DEVOTO DEPORTED TO MAUTHAUSEN CONCENTRATION CAMP

${ }^{1} \mathrm{MA}$ Riva, ${ }^{2} \mathrm{M}$ Belingheri, ${ }^{2} \mathrm{M}$ Turato, ${ }^{1} \mathrm{G}$ Cesana. ' $S$ chool of Medicine and Surgery, University of Milano Bicocca; ${ }^{2}$ School of Specialisation in Occupational Medicine, University of Milan

\subsection{6/oemed-2018-ICOHabstracts.543}

Introduction Carlo Vallardi, assistant of Luigi Devoto (18641936) at the 'Clinica del Lavoro' in Milan, is an often-forgotten figure in the history of Occupational Health.

Methods The historical investigation was conducted on documents belonging to the Ravelli Archive of the 'Fondazione Memoria della Deportazione' in Milan.

Results Vallardi was born in Milan on 2 March 1886; he belonged to a family of famous publishers. Graduated in Pavia in 1907, he began to attend as a volunteer at the Institute of Internal Medicine directed by Carlo Forlanini (1847-1918). After a short period of research in Berlin, Vallardi returned to Milan, where he began to attend the Clinica del Lavoro, focusing mainly on chronic phosphorus poisoning and lead intoxication. In 1913, he started to work at the Fatebenefratelli Hospital in Milan. During the years of World War I, he was called up as a medical officer at the front, where he conducted scientific studies on amoebic dysentery among troops. After the end of the war, he returned to Milan and continued his clinical work at the Fatebenefratelli Hospital. He openly contested Fascism. Arrested for his political ideas in March 1943, he was first transferred to the deportation camp in Fossoli, and then to the Mauthausen-Gusen concentration camp. Thanks to his knowledge of German language and his clinical skills, he was assigned to the camp hospital. As a result of this position, he managed to save the life of several prisoners, and avoid the gas chamber. Vallardi died in his hometown on 17 December 1962.

Conclusion The passion for the clinic and for scientific research - especially in occupational toxicology - and the acts of heroism in the years of deportation make Carlo Vallardi a model and an example to follow.

\section{PREVENTION OF OCCUPATIONAL DISEASES: DERIVING LESSONS FROM JOURNEY OF SURVEILLANCE}

${ }^{1}$ Seyhan Şen*, ${ }^{2}$ Gülşen Barlas, ${ }^{3}$ Selçuk Yakiştiran, ${ }^{4}$ Ahmet Özlü, ${ }^{5}$ lknur Gülsün Derin, ${ }^{6}$ Berna Ayakta Şerifi. ${ }^{1}$ Public Health Institution of Turkey, Department of Early Warning, Response and Field Epidemiology, Ankara, Turkey; ${ }^{2}$ Public Health Institution of Turkey, National Poisons Information Centre, Ankara, Turkey; ${ }^{3}$ Public Health Institution of Turkey, Occupational Health and Safety Department, Ankara, Turkey; ${ }^{4}$ Provincial Directorate of Public Health, Non-communicable Diseases Unit, Bursa, Turkey; ${ }^{5}$ Provincial Directorate of Public Health, Kocaeli, Turkey

\subsection{6/oemed-2018-ICOHabstracts.544}

Introduction To prevent and manage the economic and societal burden due to occupational diseases (ODs), countries should develop strong prevention policies, effective health surveillance and registration systems. The present study aims to contribute to development of an effective surveillance model for occupational and work-related diseases at national level for prevention and management of ODs as well as identification of priority actions and interventions in Turkey. 